\title{
Evaluation of genetic damage induced by glyphosate isopropylamine salt using Tradescantia bioassays
}

\author{
Carlos Alvarez-Moya ${ }^{1}$, Mónica Reynoso Silva ${ }^{1}$, Alma Rosa Villalobos Arámbula ${ }^{1}$, Alfonso Islas Sandoval ${ }^{1}$, \\ Hugo Castañeda Vasquez ${ }^{2}$ and Rosa María González Montes ${ }^{3}$ \\ ${ }^{1}$ Laboratorios de Genética y Péptidos Naturales, Departamento de Biología Celular y Molecular, \\ Universidad de Guadalajara, Zapopan, Jalisco, México. \\ ${ }^{2}$ Laboratorio Departamento de Mastitis Bovina, Universidad de Guadalajara, Zapopan, Jalisco, México. \\ ${ }^{3}$ Centro de Investigación Biomédica de Occidente Laboratorio de Bioquímica, \\ Instituto Mexicano del Seguro Social, Guadalajara, Jalisco, México.
}

\begin{abstract}
Glyphosate is noted for being non-toxic in fishes, birds and mammals (including humans). Nevertheless, the degree of genotoxicity is seriously controversial. In this work, various concentrations of a glyphosate isopropylamine salt were tested using two methods of genotoxicity assaying, viz., the pink mutation assay with Tradescantia (4430) and the comet assay with nuclei from staminal cells of the same plant. Staminal nuclei were studied in two different forms, namely nuclei from exposed plants, and nuclei exposed directly. Using the pink mutation assay, isopropylamine induced a total or partial loss of color in staminal cells, a fundamental criterion utilized in this test. Consequently, its use is not recommended when studying genotoxicity with agents that produce pallid staminal cells. The comet assay system detected statistically significant $(p<0.01)$ genotoxic activity by isopropylamine, when compared to the negative control in both the nuclei of treated plants and directly treated nuclei, but only the treated nuclei showed a dose-dependent increase. Average migration in the nuclei of treated plants increased, when compared to that in treated nuclei. This was probably due, either to the permanence of isopropylamine in inflorescences, or to the presence of secondary metabolites. In conclusion, isopropylamine possesses strong genotoxic activity, but its detection can vary depending on the test systems used.
\end{abstract}

Key words: glyphosate, DNA damage, comet assay, plant genotoxicity test, Tradescantia point mutation test.

Received: April 15, 2010; Accepted: September 6, 2010.

Glyphosate (N-[phosphonomethyl] glycine), usually in the form of a glyphosate isopropylamine salt, is one of the most widely used herbicides in the world, but serious contradictions exist regarding its genotoxicity. According to the U.S. Forest Service (1997), glyphosate does not show adverse effects on soil microorganisms, and the absence of genotoxic activity has also been reported by others (Owczarek et al., 1999; Busse et al., 2001; Conner and Black, 2004; De Roous et al., 2005; Dimitrov et al., 2006). Nevertheless, several works have reported high genotoxic activity by glyphosate (Li and Long,1988; Bolognesi et al., 1997; Clements et al., 1997; Peluso et al., 1998; Kaya et al., 2000; Piesova, 2005; Sivikova and Dianovsky, 2006; Sparling et al., 2006; Cavas and Könen, 2007; Grisolia, 2002; Ramirez and Cuenca, 2002) and although this herbicide has been studied using different bioassays, the results are not

Send correspondence to Carlos Alvarez-Moya. Laboratorios de Genética y Péptidos Naturales, Departamento de Biología Celular y Molecular, km 15.5 carretera a Nogales, 45020, Nogales, Mexico. E-mail: calvarez@cucba.udg.mx. conclusive, and apparently depend much on the system used (Zúñiga, 2001).

One of the most commonly used bioassays, also considered extremely reliable, for evaluating genotoxicity is the pink mutation assay with Tradescantia staminal hairs. This test is highly valued for its simplicity, and it is used to detect the effect of a wide spectrum of chemical agents and complex mixtures (Underbrink et al., 1973; Schairer et al., 1982; Ahmed and Grant, 1992; Grant and Salamone, 1994; Ma et al., 1994; Sandhu et al., 1994). In this assay, color changes in cells from floral parts are used to determine mutational events. The heterozygote condition (Aa) is used, wherein blue colour is expressed as dominant, while pink is recessive. The loss, inactivation or mutation of the dominant allele produces a pink cell (Underbrink et al., 1973).

Another sensitive test for detecting genotoxic activity, the comet assay, facilitates direct visualization of damage in genetic material from individual cells (Singh et al., 1988). This test, already used with Vicia fava (Koppen and 
Verschaeve, 1996), has also proved to be efficient with nuclei of Tradescantia (Alvarez-Moya et al., 2001).

Although the toxicity of glyphosate in plants has already been completely defined, specific genotoxic activity itself has been less studied and is less well-known. Thus, studies on plants can be very important to clarify its genotoxicity. In this work, the pink mutation test with Tradescantia staminal hairs and the comet assay systemwith staminal hair nuclei from the same plant were realized. The latter was applied to exposed nuclei and the nuclei of exposed plants.

N-(phosphonomethyl)-glycine 96\% (CAS No. 107183-6, lot 09816 PE) was obtained from Aldrich. The evaluated concentrations were $0.7,0.07,0.007$ and $0.0007 \mathrm{mM}$. In order to find the appropriate concentration range, a preliminary test was carried out, in which Tradescantia plants were exposed 10 by 10 to decreasing concentrations of that used in commercial cultures ( $70 \mathrm{mM}$ being the approximate concentration that causes death of the target plant). The initial concentration not inducing plant-death was $0.7 \mathrm{mM}$.

The Tradescantia, clone (4430) (hybrid T. subacaulis $\mathrm{X} T$. hirsutiflora), which is highly sensitive to environmental mutagens, was used here. The plants were grown under controlled conditions, with a daytime temperature of $22^{\circ} \mathrm{C}$ and night-time temperatures ranging from 16 to $18^{\circ} \mathrm{C}$. For each concentration, 30 inflorescences were immersed for $3 \mathrm{~h}$ in $250 \mathrm{~mL}$ of the isopropylamine concentration to be tested, which signifies around 15 flowers (1500 to 3000 stamen hairs) to be assayed daily in each experimental group. The same number of inflorescences and time-span were used with both positive (nitrosodiethylamine (NDEA) 1 $\mathrm{mM}$ ) and negative (Hoaglands solution) controls. The experiment was carried out in duplicate. Subsequently, the inflorescences were washed with distilled water and placed in Hoagland's solution until the moment of reading.

A part of the inflorescences was used for pinkmutation counting, whereas nuclei extracted from the other part were employed in comet assaying. The stamen hairs in each experimental point were observed daily from the $7^{\text {th }}$ to $14^{\text {th }}$ day after application of isopropylamine, a period during which the pink mutations become clearly visible. The mutational events, as well as the number of observed hairs and cells, were scored under a dissecting microscope. The frequency of pink cells (events per 1000 cells) was established according to the methodology described by Underbrink et al. (1973). The mean values of pink mutations are shown with $95 \%$ confidence intervals $(p<0.05)$.

Staminal hair-cell nuclei from treated plants were separated according to Alvarez-Moya et al. (2001). The stamens of ten flowers from treated plants for each experimental point, obtained on the $6^{\text {th }}$ day after treatment, when mutation is becoming evident, thus indicating the absence of repair (Underbrink et al., 1973), were then placed into a cold mortar with $500 \mu \mathrm{L}$ of Honda buffer $(0.44 \mathrm{M}$ sucrose, $2.5 \%$ Ficoll (type 400 ), $5 \%$ Dextran T-40, 25 mM Tris- $\mathrm{HCl}$
(pH 8.5), $10 \mathrm{mM} \mathrm{MgCl} 2,10 \mathrm{mM} \beta$-mercaptoethanol, and $2.5 \%$ Triton X-100), to then be homogenized for $2 \mathrm{~min}$. Subsequently, the mixture was filtered through a nylon mesh $(80 \mu \mathrm{m})$. The nuclei were separated by centrifugation at $999 \mathrm{~g}\left(4^{\circ} \mathrm{C}\right)$ for $3 \mathrm{~min}$. Under these conditions, gradient centrifugation and freezing in liquid nitrogen to break the cell wall were not necessary for separating nuclei. These were then washed three times in $5 \mathrm{~mL}$ of a wash solution (sucrose $0.4 \mathrm{M}$, Tris-Base $50 \mathrm{mM}$ and $\mathrm{MgCl}_{2}, \mathrm{pH} 8.5$ ), resuspended in $200 \mu \mathrm{L}$ of the same solution, and then stored at $-20{ }^{\circ} \mathrm{C}$ until electrophoresis. Slides were prepared according to Singh et al. (1988).

The nuclei of untreated plants were used in the comet assay, according to Singh et al. (1988) and Alvarez-Moya et al. (2001). Stamens of ten flowers were used for each concentration of glyphosate isopropylamine salt and respective controls. The same methodology was employed to obtain the previously mentioned nuclei. Slides with nuclei were then exposed for $3 \mathrm{~h}$ at $25^{\circ} \mathrm{C}$ to each concentration of glyphosate isopropylamine salt to be probed, washed 3 times with distilled water, and then kept at $4{ }^{\circ} \mathrm{C}$ to avoid the repair of the induced damage. The experiment was repeated twice.

To induce nuclear lysis and facilitate DNA unfolding, all the slides were immersed in a lysis buffer $(2.5 \mathrm{M} \mathrm{NaCl}$, $100 \mathrm{mM} \mathrm{Na}{ }_{2}$ EDTA, $10 \mathrm{mM}$ Tris-HCl, $1 \%$ sodium lauryl sarcosine, $1 \%$ Triton $\mathrm{X}-100$, and $10 \% \mathrm{DMSO}, \mathrm{pH} 10$ ) for $1 \mathrm{~h}$ at $4{ }^{\circ} \mathrm{C}$. These were then placed in a horizontal electrophoresis system with a high $\mathrm{pH}$ buffer $(30 \mathrm{mM} \mathrm{NaOH}$, $1 \mathrm{mM} \mathrm{Na}_{2}$ EDTA, $\mathrm{pH}$ 13) for 45 min to allow unwinding of DNA prior to electrophoresis which was carried out for $15 \mathrm{~min}$ at $1.0 \mathrm{~V} / \mathrm{cm}$ with anaccompanying amperage of approximately $200 \mathrm{~mA}$. The same electrophoresis unit and power supply were used throughout the study (Hartmann et al., 2003). In order to avoid additional DNA damage, all the steps described above were carried out under yellow light.

Following electrophoresis, the slides, first gently washed to remove alkali, were then immersed in a neutralization buffer (0.4 M Tris-Base, pH 7.5) for 5 min. Gels were stained with ethidium bromide $(100 \mu \mathrm{L}$ at $20 \mu \mathrm{g} / \mathrm{mL})$ for $3 \mathrm{~min}$ and then rinsed three times with distilled water. The preparation was then coverslipped. Fluorescence microscopy used to examination the slides employed a light microscope equipped with a $515-560 \mathrm{~nm}$ excitation filter. Nuclei were observed at 40X magnification, and migration determined by the visual scoring of tail length, according to published protocols (Hartmann et al., 2003). Approximately 50 nuclei per slide and two slides for each experimental point and controls, were evaluated.

The data obtained were submitted to one-way analysis of variance testing (ANOVA) using the Co Stat program (Ma et al., 1994).The Dunnett test was used for comparing the negative control with data from the nuclei of exposed plants and the exposed nuclei of healthy ones. Each experiment was repeated twice. Depending on flower- 
availability, the number of hairs proved to be different in each treatment. Results were considered statistically significant at $\mathrm{p}=0.05$.

The pink mutation assay is highly efficient for evaluating genotoxicity (Underbrink, 1973; Grant and Salamone, 1994; Ma et al., 1994). Nevertheless, it was not possible to obtain the average of pink mutation frequency from the $7^{\text {th }}$ to $14^{\text {th }}$ day after treatment in glyphosate isopropylamine salt, since all the concentrations (0.07-0.0007 mM) induced partial or total loss of color in staminal cells, this affecting the fundamental criterion for scoring genotoxic activity of a chemical compound, viz., the change in color from blue (Aa) to pink (aa).

The pink mutation assay in Tradescantia turned out to be inadequate for detecting isopropylamine mutagenic activity, and most certainly for other chemical agents potentially capable of clarifying staminal cells. Possibly, the use of inadequate bioassays for detecting genotoxicity in this herbicide, has generated contradictory information, as has also occurred in other cases (Zúñiga, 2001). Although the pink mutation assay was not a good option for studying the genotoxic activity of glyphosate, which was not discarded in Tradescantia, we performed the comet assay system on the nuclei of the same plant and results were very different.

The comet assay is a valuable and sensitive tool for detecting genetic damage in individual cells (Singh et al., 1988). According to Alvarez-Moya et al. (2001), there is also a protocol that simplifies this assay in Tradescantia staminal nuclei. A significant difference $(p<0.01)$ was evidenced when comparing controls and the different isopro- pylamine concentrations in both treated plants and treated nuclei (Figure 1).

Furthermore, beginning at $0.07 \mathrm{mM}$, there was also evidence of an increase in dose-dependence, probably due to the direct contact of isopropylamine with nuclear DNA. These results are compatible with several other reports (Ramirez and Cuenca, 2002; Grisolia, 2002; Cavas and Konen, 2007). Moreover, there was an increase in mean migration in the nuclei of exposed plants, when compared to exposed nuclei.

We believe that there are two plausible explanations for this behavior, namely (1) the formation of a secondary mutagenic metabolite of isopropylamine in the Tradescantia plants but not in the nuclei (Torstensson et al., 1989), and (2) the longer exposure time in assayed nuclei from treated plants. It is worthy of note that, although the treatment was administered for $3 \mathrm{~h}$ and the inflorescences washed extensivelyto eliminate residues, glyphosate (or its possible secondary metabolite) present within the plant for 6 days could increase genetic damage. This also might explain why a clear relationship between dose and response was not observed. Based on these results, we believe that isopropylamine used in commercial farming can induce genetic damage, depending on the dose used and the physiological characteristics of the plants exposed to it.

The selection of a bioassay to detect genotoxicity is very important for obtaining confiable results. As was observed for the pink mutation test, isopropylamine interferes with evaluation criteria, thereby generating incorrect results. The comet assay system clearly detected the genotoxicity of isopropylamine, but the magnitude varied depending on the type of exposure.

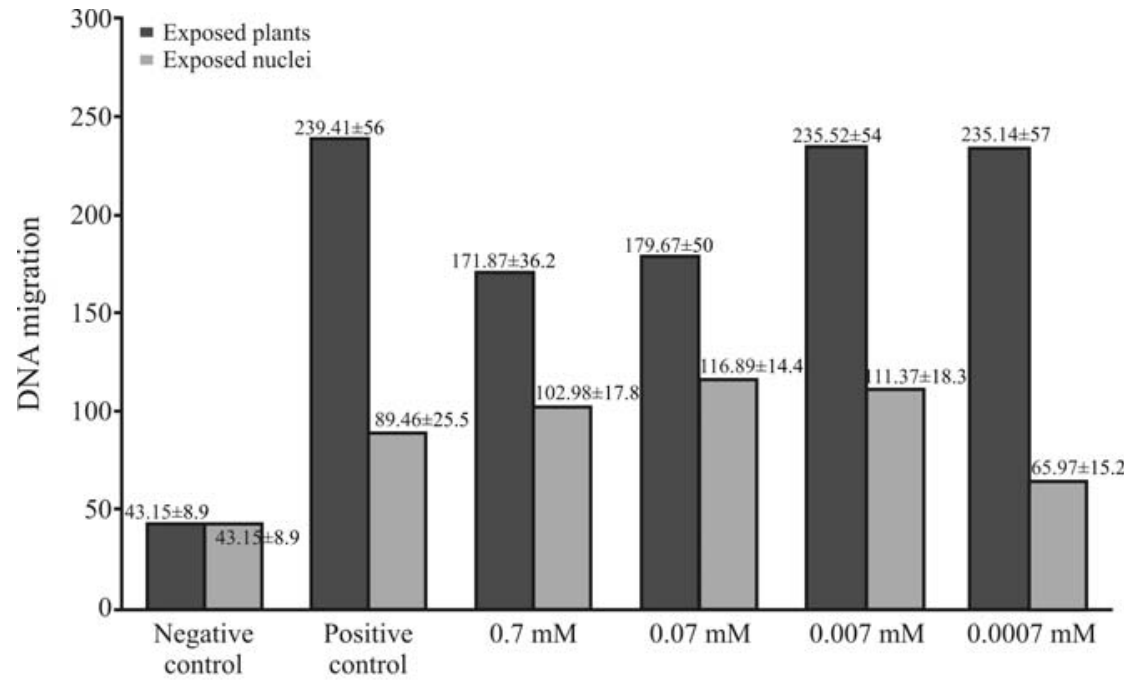

Isopropylamine concentrations

Figure 1 - Average tail length and standard deviation in $\mu \mathrm{m}$ of Tradescantia staminal hair nuclei of both plants and nuclei exposed to different concentrations of isopropylamine salt of glyphosate and to two controls, negative (Hoaglands solution) and positive (EMS $1 \mathrm{mM}$ ). The mean tail length of the negative control in both exposed plants and nuclei was significantly different $(\mathrm{p}<0.05)$, when compared with the positive control and each glyphosate concentration. Data are an average of the experiments run in duplicate. 


\section{Acknowledgments}

This work was partially supported by the University of Guadalajara-Coecytjal de México 401.

\section{References}

Ahmed M and Grant WF (1992) Cytological effects of the pesticides phodrin and bladex on Tradescantia and Vicia faba root tips. Can J Gen Cytol 14:157-165.

Alvarez-Moya C, Santerre-Lucas A, Zúñiga-González G, Torres-Bugarín O, Padilla-Camberos E and Feria-Velasco A (2001) Evaluation of the genotoxic activity of maleic hydrazide, ethyl methane sulfonate, and N-nitrosodiethylamine in Tradescantia. Salud Púb Méx 43:563-569.

Bolognesi C, Bonatti S, Degan P, Gallerani E, Peluso M, Rabboni R, Roggieri P and Abbondandolo A (1997) Genotoxic activity of glyphosate and its technical formulation roundup. J Agric Food Chem 45:1957-1962.

Busse MD, Ratcliff AW, Shestak CJ and Powers RF (2001) Glyphosate toxicity and the effects of a long-term vegetation control on soil microbial communities. Soil Biol Biochem 33:1777-1789.

Cavas T and Könen S (2007) Detection of cytogenetic and DNA damage in peripheral erythrocytes of goldfish (Carassius auratus) exposed to glyphosate formulation using the micronucleus test and comet assay. Mutagenesis 22:263-268.

Clements C, Ralph S and Petras M (1997) Genotoxicity of select herbicides in Rana catesbeiana tadpoles using the alkaline single cell gel DNA electrophoresis (comet) assay. Environ Mol Mutagen 29:277-288.

Conner DE and Black MC (2004) Evaluation of lethality and genotoxicity in the freshwater mussel Utterbackia imbecillis (Bivalvia, Unionidae) exposed singly and in combination to chemicals used in lawn care. Arch Environ Contam Toxicol 46:362-371.

De Roous AJ, Blair A, Rusiecki JA, Hoppin JA, Svec M, Dosemeci M, Sandler DP and Alavanja MC (2005) Cancer incidence among glyphosate-exposed pesticide applicators in the agricultural health study. Environ Health Perspect 113:49-54.

Dimitrov BD, Gadeva PG, Benova DK and Bineva MV (2006) Comparative genotoxicity of the herbicide roundup, stomp and reglone in plant and mammalian test systems. Mutagenesis 21:375-382.

Grant WF and Salamone MF (1994) Comparative mutagenicity of chemicals selected for test in the International Program on chemical safety's collaborative study on plant systems for the detection of environmental mutagens. Mutat Res 310:187-209.

Grisolia CK (2002) A comparison between mouse and fish micronucleus test using cyclophosphamide, mitomicin and various pesticides. Mutat Res 518:145-150.

Hartmann A, Agurell E, Beever C, Brendler-Schwaab S, Burlinson B, Clay P, Collins A, Smith A, Speit G, Thybaud V, et al. (2003) Recommendations for conducting the in vivo alkaline comet assay. Mutagenesis 18:45-5.

Kaya B, Creus A, Yanikoglu A, Cabre O and Marcos R (2000) Use of the Drosophila wing spot test in the genotoxicity testing of different herbicides. Environ Mol Mutagen 36:40-46.
Koppen G and Verschaeve L (1996) The alkaline comet on plant cells: A new genotoxicity test for DNA breaks in Vicia faba roots cells. Mutat Res 360:193-200.

Li AP and Long TJ (1988) An evaluation of the genotoxic potential of glyphosate. Fund Appl Toxicol 10:537-546.

Ma TH, Cabrera GL, Cebulska-Wasilewska A, Chen R, Loarca F, Vandenberg AL and Salamone MF (1994) Tradescantia stamen hair mutation bioassay. Mutat Res 310:211-220.

Owczarek M, De Marco A, De Simone C and Ambrosio CD (1999) Evaluation of the toxic and genotoxic activity of some pesticides in to soil-plant system. In: Human and Environmental Exposure to Xenobiotics. Proceedings of the IX Symposim Pesticide Chemistry, Cremona, pp755-762.

Peluso M, Munnia A, Bolognesi C and Parodi S (1998) ${ }^{32}$ P-postlabeling detection of DNA adducts in mice treated with the herbicide roundup. Environ Mol Mutagen 31:55-59.

Piesova E (2005) The effect of glyphosate on the frequency of micronuclei in bovine lymphocytes in vitro. Acta Vet Beograd 55:101-109.

Ramirez V and Cuenca P (2002) DNA damage in banana farm workers exposed to insecticides in Limon, Costa Rica. Rev Biol Trop 50:507-518.

Sandhu SS, De-Serres FJ, Gopalan HN, Grant WF, Svendsgaard D, Veleminsky J and Becking GC (1994) Environmental monitoring of genotoxicity with plant systems. Mutat Res 310:257-263.

Schairer LA, Sautkulis RC and Tempel NR (1982) Monitoring ambient air for mutagenicity using the higher plant Tradescantia. In: Tice RR, Costa DL and Schaich KM (eds) Genotoxic Effects of Airborne Agents. Plenum Press, New York, pp 123-140.

Singh N, McCoy M, Tice R and Schneider L (1988) A simple technique for quantitation of low levels of DNA damage in individual cells. Exp Cell Res 175:184-199.

Sivikova K and Dianovsky J (2006) Cytogenetic effect of technical glyphosate on cultivated bovine peripheral lymphocytes. Int J Hyg Environ Health 209:15-20.

Sparling DW, Matson C, Bickham J and Doelling-Brown P (2006) Toxicity of glyphosate as Glypro (R) and LI700 to red-eared slider (trachemys scripta elegans) embryos and early hatchlings. Environ Toxicol Chem 25:2768-2774.

Torstensson NT, Lundgren LN and Stenström J (1989) Influence of climatic and edaphic factors on persistence of glyphosate and 2,4-D in forest soils. Ecotoxicol Environ Saf 18:230-9.

U.S. Forest Service (1997) Glyphosate: Herbicide Information Profile. Pacific Northwest Region. United Stated Drug Administration, Washington, $25 \mathrm{pp}$.

Underbrink AC, Schairer LA and Sparrow AH (1973) Tradescantia stamen hairs: A radiobiological test system applicable to chemical mutagenesis. In: Hollaender A (ed) Chemical Mutagens: Principles and Methods for their Detection. Plenum Press, New York, pp 71-207.

Zúñiga GG (2001) Sistemas de detección de daño genético. In: Álvarez-Moya C (ed) Genética, Ambiente y Salud. 2nd edition. Universidad de Guadalajara, Guadalajara, pp 127-150.

Associate Editor: Catarina S. Takahashi

License information: This is an open-access article distributed under the terms of the Creative Commons Attribution License, which permits unrestricted use, distribution, and reproduction in any medium, provided the original work is properly cited. 